\title{
A Study on Ergonomics for Employee Wellness
}

\author{
Anilambica Kata, Dr. V. Srinivasa Prasad
}

\begin{abstract}
The nature of work in modern society is changing rapidly, and competition in the job market is getting more intense. This requires competence from workers and demands them to update their knowledge, skills, and attitudes in order to remain productive and retain their attractiveness in the job market. On the other hand, skilful employees are a company's most important competitive assets, and so it is worth to up- skill the employees by providing training at regular intervals on process and also on governing themselves from workplace illness. Thus the present study is an attempt to create awareness on ergonomics that impact employee performance. The significance and prominent role of ergonomics is reviewed by discussing its association with other scientific disciplines and by ascribing types of ergonomics and its principles and applications towards employee wellness.
\end{abstract}

KEYWORDS- Ergonomics, physical, Cognitive, Organisational ergonomics, Human, Machine, Environment, Types of ergonomics, ergonomic disciplines.

\section{INTRODUCTION}

In today's world of slaughtering competition, everyone wants to give their best to retain the job, erstwhile it became essential to spend more time at work place for better growth in terms of better earning and performance. This is the time, people just start getting physical issues, it could start with a head ache or back ache which people usually ignore at the age of 20s and 30s. In the present times, the blend of product qualities is one among most appropriate competitive factors, while technological performance is no longer the single most important quality, since the level of importance of other qualities such as employee comfort, satisfaction or usability increases.

Manuscript received July 17, 2020

Anilambic Kata, Research Scholar, Acharya Nagarjuna University, Guntur, Andhra Pradesh, India, Mob: 9177886834, (e-mail: hranilambica@gmail.com)

Dr.V. Srinivasa Prasad, Director P.G \&U.G (UnAided Courses), V.R.S\& Y.R.N College, Chirala, Andhra Pradesh, India, Mob: 9866306818
Branches of ergonomics that are still developing, such as contentment, ease or cognitive engineering, have been tentatively considered in the context of this competitiveness, as a means of adding use related value to products.

\section{REVIEW OF LITERATURE}

The Physical, Psychological and Organisational working conditions are considered as the major barriers an employee to face in the present corporate world. The poor working conditions will make it difficult to perform tasks within the stipulated time. Moreover, these factors will cause physical and psychological stress to the workers. It will ultimately cause negative affect on the health and well-being of the employee which in turn most likely reduces the efficiency of an individual to perform task thus affecting the overall performance of the individual and organization as a whole. Ergonomics (or human factors) is referred as a scientific discipline that deals with interactions among humans and other elements of a system, and applies theory, principles, data and methods to design in order to improve human well-being and overall performance of the system (International Ergonomics Association, 2003). Ergonomic consultant contribute to the design and evaluation of tasks, jobs, products, environments and systems in order to make them compatible with the needs, abilities and limitations of people. Thus, it is said as "Human engineering "or "Human Factor Engineering" (Aranca-India Brand Equity Foundation-2019). Ergonomics is a study of science that deals with the 'fit' amid of or between people and their work. It places people first, considering capabilities and limitations of the individual.

The significance and prominent role of ergonomics can be reviewed by discussing its association with other scientific disciplines and by ascribing types of ergonomics and its principles and applications.

\section{ERGONOMICS RELATED DISCIPLINES AND APPLICATIONS TO WORKPLACE}

To optimize the interaction between work, Worker and Work environment, the Contributors to ergonomics/human factors concepts include the following:
A. Anthropometry
B. Biomechanics
C. Mechanical engineering
D. Industrial design
E. Information design
F. Kinesiology 


\section{G. Physiology \\ H. Psychology}

\section{A. Anthropometry}

"Anthropometry is the science of measurement of physical geometry, mass properties, and strength capabilities of the human body"[14]. It is an essential element in design of the workspace to fit the workman [2].

Application of anthropometry in the workplace is as follows:

1. To measure bodily postures and distance that has to be maintained to access controls/system with which people interact;

2. To specify measures that has to be taken from hazards such as surrounding equipment/system;

3. To help the workmen in achieving comfort level at work

4. To reduce musculoskeletal disorders (MSD) thereby enrich the performance[14].

\section{B. Biomechanics}

Ergonomists makes use of biomechanical principles about the functional anatomy of the living body to eliminate stress, problems of occupational health and to promote occupational safety and industrial productivity[8].

\section{Mechanical Engineering}

This branch of science traces in almost every aspect of modern life including human body, a highly complex machine, erstwhile by combining principles of physics and mathematics to design, analyse, manufacture and maintain machines and tool physical, (Columbia Engineering) ${ }^{7}$. On the other hand the ergonomics as branch of science that is concerned with the "fit" between people and their technological tools and environment helps in design and development of a new machine or equipment to ensure comfort and human well -being.

\section{Industrial Design}

According to Industrial Design Program, Carlton University- Industrial design experts define the Ergonomics, appearances, material, features of the all types of products we use daily from clothing's to electronic, sports goods, tools and other regular /specific equipment [10]. The two most crucial disciplines of industrial design are Anthropometry and Ergonomics, where former is the element of ergonomics that scales human stature and strength and later is a studies the fit between man-environment both anthropometry and Ergonomics play a essential role in industrial design. These two components such as scale and capabilities of humans deliver critical strategies for the effective development of man-machine/product interface design[16].

\section{E. Kinesiology}

Kinesiology is branch of science that is concerned with the human or non-human body movement. Kinesiology addresses the principles and mechanisms of movement in physiological, biomechanical, and psychological. Application of Kinesiology at work place: i. Evaluate Bodily Postures.

ii. Organising Training programs on physical Education.

iii. To reduce Work Place Injury (WPI) and improve Man -Machine Interaction.

iv. Appointment of Kinesiologist at work place helps in promoting workplace wellness through on-site rehabilitative activities like stretches and exercise programs[18].

\section{F. Physiology}

"Physiology is the branch of biology that is concerned with the study of mechanisms of living organisms to the integrated behaviour of the whole body and the influence of the external environment. The study helps us to know how a healthy body works, responds and fine-tunes to the day to day challenges in life; It helps us to determine what goes wrong in body makes us fall sick" [13].

\section{G. Psychology}

"Psychology is the study of science that is concerned with mind and behaviour"[17].

Psychological Ergonomics Factors that influence the employee are:

- Job and work environment

- Balance between work and personal life

- Individual attitude, characteristics and thought process.

\section{TYPES OF ERGONOMICS}

There are many terms are used for Ergonomics such as Engineering psychology, Human Factors, Human Factor Engineering, and Human Engineering more or less they all synonymously the same.

"Human-System interface (HSI) technology has clearly proposed five distinguishable subparts, in which the first four subparts are called Micro Ergonomics, and the fifth subpart is called as the macro ergonomics"[4].

i. Human-Machine interface technology or Hardware Ergonomics

ii. Human-Environment interface technology, or Environmental Ergonomics

iii. Human-Software interface technology, or Cognitive ergonomics

iv. Human-Job interface technology, or Work design ergonomics

v. Human-Organization interface technology, or Macro ergonomics

According to Human Factors and Ergonomics Society, 1998 "The overall goal of the discipline is to improve the human condition, including health, safety, comfort, productivity, and quality of life" [7] .According to IEA the three main domains of Specializations within Ergonomics are:

A. Physical Ergonomics

B. Cognitive Ergonomics

C. Organizational Ergonomics [9], are discussed in our study.

D. System Ergonomics 


\section{A. Physical Ergonomics}

After the human resources, the second largest financial overhead for most of the organisations is the organization's workspace i.e., the physical environment/office settings from where the employee is supposed to carry out their work[6]. The Physical disciplines of physical Ergonomics are anthropometry, biomechanics, physiology, and the physical environment

According to Wilson the physical ergonomics includes fit, clearance, reach, access, tolerance, workload, manual handling, health and safety, workplace layout, displays and controls, product and equipment design, environment, tools[11].The physical ergonomics is referred as a science of fitting work environment and occupational/work demands to the capabilities of the workmen. It is an approach or method of dealing with occupational health hazards - such as work-related musculoskeletal disorders [5].The focus areas of physical ergonomics includes the unintended consequences due to repetitive motion, materials handling, awkward postures and also deals with workplace safety, comfort in the use of portable devices, keyboard design, and the work environment (Usability ergonomic settings .

Physical ergonomics can be itemized as a set of ten interrelated principles:

- Work in neutral postures

- Reduce excessive force

- Keep everything in easy reach

- Work at proper heights

- Reduce excessive motions

- Minimize fatigue and static load

- Minimize pressure points

- Provide clearance

- Move, exercise, and stretch

- Maintain a comfortable environment

\section{B. Cognitive Ergonomics}

The domain of cognitive ergonomics is defined by IEA as being "concerned with mental processes, such as perception, memory, reasoning, and motor response, as they affect interactions among humans and other elements of a system"[5]. The most associated features of cognitive Ergonomics includes man- Machine interaction specifically human-computer interaction encompassing features like the design, organization, and operation of user interfaces but also includes the work related stress such as mental workload, job discontentment, job monotony and stress[12].

Relevant topics include

- Mental workload

- Decision making

- $\quad$ Skilled performance

- Human-computer interaction

- Human reliability

- Stress

- $\quad$ Training[3] ergonomics is concerned workplace setting. The related explained in the previous section. body of knowledge)[15].As an instance of physical

\section{Organisational Ergonomics/Macroergonomics}

The organisational ergonomics is also referred as social ergonomics which deals with attitudes, motivation, satisfaction, job and team design, hours and patterns of work, pacing, implementation of change[11].

Application of macro/Organisational ergonomics Approaches

- To reduce Work related injuries

- Information and communication technology (ITC) and changes in work life.

- Hazard Management

- Organisation Change( Large Organisations)

- Community Ergonomics

- Technology Transfer

- Virtual organisations

- Training and development

\section{Systems Ergonomics}

Is the combination of physical, cognitive and social ergonomics. It is the most successful ergonomics, which includes analysis, design and evaluation integrates the physical, cognitive and social.

Relationship Between Human(H), Machine(M), Environment(E)

Table 1: Basic Interactions in a work system and their evaluation

\begin{tabular}{|c|c|}
\hline Interaction & Evaluation \\
\hline $\begin{array}{l}\mathrm{H}>\mathrm{M} \text { : The Basic } \\
\text { control actions } \\
\text { performed by the } \\
\text { human on the machine. } \\
\text { Application of large } \\
\text { forces, fine tuning of } \\
\text { controls, maintenance } \\
\text { etc. }\end{array}$ & $\begin{array}{l}\text { Anatomical: Body limb posture } \\
\text { and movement, size of forces, } \\
\text { cycle time and frequency of } \\
\text { movement, muscular fatigue. } \\
\text { Physiological: work rate, } \\
\text { fitness of work force, } \\
\text { physiological fatigue. } \\
\text { Psychological: } \\
\text { requirements, mental workload, } \\
\text { parallel/sequential processing } \\
\text { of information, compatibility of } \\
\text { action. }\end{array}$ \\
\hline $\begin{array}{l}\mathrm{H}>\mathrm{E} \text { Effects of the } \\
\text { human on the local } \\
\text { environment. Human } \\
\text { emit nose, heat, carbon } \\
\text { dioxide, etc. }\end{array}$ & 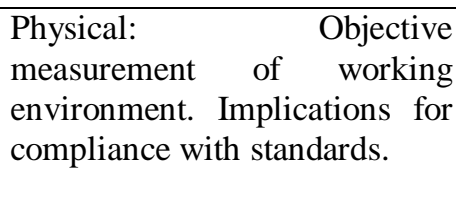 \\
\hline $\begin{array}{l}\text { M }>\mathrm{H} \text { : feedback and } \\
\text { display of information. } \\
\text { Machine may exert } \\
\text { forces on the human } \\
\text { due to vibration, } \\
\text { acceleration, etc. } \\
\text { Machine surfaces may } \\
\text { be excessively hot or } \\
\text { cold and a threat to the } \\
\text { human health }\end{array}$ & $\begin{array}{l}\text { Anatomical: design of controls } \\
\text { and tools. } \\
\text { Physical: } \\
\text { measurement of vibrations, } \\
\text { reaction Forces of powered } \\
\text { machines, noise and surface } \\
\text { temperate in the workplace. } \\
\text { Physiological: Does sensory } \\
\text { feedback exceed physiological } \\
\text { thresholds? } \\
\text { Psychological: application of } \\
\text { grouping principles to design } \\
\text { of face panels, and graphic }\end{array}$ \\
\hline
\end{tabular}




\begin{tabular}{|l|l|}
\hline & $\begin{array}{l}\text { displays. Information load. } \\
\text { Compatibility with user } \\
\text { expectations. }\end{array}$ \\
& \\
& \\
\hline $\begin{array}{l}\text { M>E: Machine may } \\
\text { alter working } \\
\text { environment by } \\
\text { emitting noise, heat, } \\
\text { noxious gases. }\end{array}$ & $\begin{array}{l}\text { Mainly by industrial engineers } \\
\text { and industrial hygienists }\end{array}$ \\
\hline $\begin{array}{l}\text { E>H: The environment } \\
\text { in turn may influence } \\
\text { humans ability to } \\
\text { interact with machine } \\
\text { or to remain part of the } \\
\text { work system }\end{array}$ & $\begin{array}{l}\text { Physical/Physiological: Noise, } \\
\text { lighting and temperature survey } \\
\text { of entire facility. }\end{array}$ \\
\hline $\begin{array}{l}\text { E>M: The environment } \\
\text { may affect the } \\
\text { functioning of the } \\
\text { machine. It may cause } \\
\text { overheating or freezing } \\
\text { of components, }\end{array}$ & $\begin{array}{l}\text { Industrial engineers and } \\
\text { industrial } \\
\text { maintenance of personnel, } \\
\text { facilities management }\end{array}$ \\
\hline
\end{tabular}

$\mathrm{H} \rightarrow$ Human, $\mathrm{M} \rightarrow$ Machine, $\mathrm{E} \rightarrow$ Environment

The above table gives an illustration about Human, Machine and environment interactions at work system which help in reducing the imbalances and to maintain a workplace settings fit to the workforce.

\section{CONCLUSION}

The study affirms that there is a need to balance the interactions between the Human, Machine and Environment which plays a very prominent role for smooth and prosperous running of the organisation. The study also divulged that Ergonomics has broader perceptive as it is an amalgamation of various scientific disciplines. However, the study attempted to create awareness on the types of ergonomics and its application to workplace. This would definitely helpful for the enrichment of individual awareness on workplace ergonomics as well as organisation performance by promoting the employees comfort, health, safety and well-ness.

\section{REFERENCES}

[1] Harris, D. (Ed.). (2019). Engineering Psychology and Cognitive Ergonomics. 16th International Conference, EPCE 2019, Held as Part of the 21st HCI International Conference. 11571. Orlando, FL, USA,: Spinger.

[2] A.S.NICHOLSON. (2014). Anthropometry in Workspace Design. In Advances in Human Factors/Ergonomics. Elsvier.
[3] Bush, P. M. (2012). Ergonomics: Foundational Principles, Applications, and Technologies. (W. Karwowski, Ed.) London: Taylor \& Francis Group.

[4] Columbia Engineering. (n.d.). Columbia University in the City of New York. Retrieved 2020, from https://me.columbia.edu/

[5] ERGOPIUS. (2020, march 7). ERGOPIUS. (M. Middlesworth, Editor) Retrieved 2020, from Ergonomics 101: The Definition, Domains, and Applications of Ergonomics.

[6] Evans, J. M. (2005). Physical Work Environment. In E. K. Julian Barling (Ed.), Handbook of Work Stress. sage publications.

[7] Hal W. Hendrick, B. M. (2002). Macroergonomics theory, methods, and applications. (g. Salvendy, ed.) London: Lawrence Erlbaum Associates, Publishers .

[8] Haque Md, K. M. (2015). ERGONOMICS, BIOMECHANICS \& MUSCULOSKELETAL DISORDER- A REVIEW. International Journal of Electrical and Electronics Engineers, 07(1).

[9] Helander, M. (2006). A GUIDE TO HUMAN FACTORS (second ed.). Newyork: Taylor \& Francis Group.

[10] Industrial Designers Society of America. (2019, May 21). INDUSTRIAL DESIGNERS SOCIETY OF AMERICA. Retrieved 05 2020, from https://www.idsa.org/news/dblog/what-id: https://www.idsa.org/news/dblog/what-id

[11] John R. Wilson, N. C. (2005). Evaluation of Human Work (3 ed.). CRC.

[12] John W. Schwieter, A. F. (2017). The Handbook of Translation and Cognition. John Wiley \& Sons, Inc.

[13] physoc.org. (n.d.). The Physiologcal society. Retrieved 05 2020, from physoc.org: https://www.physoc.org/explore-physiology/what-isphysiology/

[14] Prado-Lu, J. L. (2007). Anthropometric measurement of Filipino manufacturing workers. International Journal of Industrial Ergonomics.

[15] Usability body of knowledge. (n.d.). physical ergonomics. Retrieved 2020, from Usability body of knowledge: https://www.usabilitybok.org/physicalergonomics

[16] UTS handbook 2020. (2018). Informing Industrial Design. Retrieved from University of technology Sydeney: https://handbook.uts.edu.au/subjects/84122.html

[17] wikipedia.org. (n.d.). Psychology. Retrieved from Wikipedia, the free encyclopedia: https://en.wikipedia.org/wiki/Psychology\#cite_noteFernald-1

[18] workplace testing.com. (2018, June 20,). kinesiology. Retrieved may 13, 2020, from workplace testing.com: https://www.workplacetesting.com/definition/1577/ki nesiology 